\title{
CONFLICT AVOIDANCE IN INTER VIVOS TRUSTS OF MOVABLES
}

\author{
WiLIIAM Tucker Dean*
}

I

InTRODUCTION

There are two principal aspects of conflict avoidance: one involves the care and foresight of astute counsel who, knowing the rules of law, or perhaps the confusion of rules, in a given area, advises clients and draws documents so as to minimize the likelihood of a conflict of laws; the other, apparently not of great interest to AngloAmerican lawyers and scholars, involves the minimization of the conflict of laws by legislation directed specifically at the problem. Ideally, this latter aspect aims not so much at the avoidance of conflicts, which are implicit in a community comprised of many separate jurisdictions, but rather at so precise and lucid a delineation of conflicts rules that attorneys, in counseling and drafting, will be able to act with reasonable certainty and confidence. Actually, of course, legislative reaction to the conflict of laws has consisted principally of ignoring the problem and consigning to the judiciary the essentially legislative function of fashioning appropriate rules; and, as a result, there have been superadded to the inevitable conflicts between the internal laws of different jurisdictions conflicts between the rules of the various jurisdictions for resolving conflicts of laws. ${ }^{1}$ Accordingly, this article will rather concern itself primarily with conflict avoidance in inter vivos trusts of movables in the light of existing rules, or the confusion over what the existing rules are; and only to a limited extent will it consider conflict avoidance in this field by legislative means, which, as a matter of fact, cannot be isolated from the larger problem of general conflicts legislation. ${ }^{2}$

The trusts which will be considered are the bankers' "living trusts," the lawyers' "trusts inter vivos," and not the testamentary trusts, which are more appropriate to "Conflict Avoidance in Succession Planning." Attention will be concentrated on the conflict of laws of the United States simply because most of the material available relates thereto. Avoidance of the conflict of tax laws will not be discussed-the topic

-A.B. 1937, Harvard College; J.D. 1940, University of Chicago Law School; M.B.A. 1947, Graduate School of Business Administration, Harvard University. Member of the New York and District of Columbia bars; Associate Professor of Law, Cornell Law School, since 1953. Author, Conflict of Laws, in 1947-r954 Annual Survey of AMIerican Law; and Jurisdiction to Enforce Wife's Right to Support Notwithstanding Foreign Divorce Enttrled to Full Faith and Credit (N. Y. Law Rev. Comm'n, Legis. Doc. No. 65(K) (x953)). Contributor to legal periodicals.

1 See Dean, The Conflict of Confict of Laws, 3 Stan. L. Rev. 388 (195I).

2 Id. at 401 et seq.; Elliott E. Cheatham, Noel T. Dowling, Herbert F. Goodrich, Erwin N. Griswold, Cases and Materials on Conflict of Laws 649-57 (2d ed. 194r); of. Nussbaum, Sources of Conflict of Laws Rules in Civil Law, id. at 6-10.

${ }^{3}$ See Scoles and Rheinstein, Conflict Avoidance in Succession Planning, infra 499-532. 
has come to be one for the tax expert ${ }^{4}-$ nor will the conflict over jurisdiction be treated. 5 The type of trust to be examined will be the express trust, ordinarily for family settlement, and will not include charitable trusts, business insurance trusts, investment trusts, community trusts, or trusts in connection with corporate mortgages, to mention some of the many other possibilities.

By "trust," of course, reference is made to that remarkable institution peculiar to Anglo-American law consisting of ${ }^{6}$

... a fiduciary relationship with respect to property, subjecting the person by whom the property is held to equitable duties to deal with the property for the benefit of another person, which arises as a result of a manifestation of an intention to create it;

the parties to which have been described in these words: ${ }^{7}$

(r) The person who creates a trust is the settlor.

(2) The property held in trust is the trust property.

(3) The person holding property in trust is the trustee.

(4) The person for whose benefit property is held in trust is the beneficiary.

The classification of property as "movable" or "immovable" is peculiar to the conflict of laws and avoids many of the diffculties inherent in the similar, but not identical, classifications of "personalty" and "realty." For the purposes of the conflict of laws, immovables include all interests in land and whatever is attached permanently thereto, while movables include all other varieties of property. Although movables are typically tangible articles, such tangibles are rarely conveyed in trust by settlors; it is rather intangible property, such as corporate securities, government bonds, and the like, of which trusts of movables are generally comprised. While some securities, such as negotiable instruments, are usually treated as tangibles because the property right is said to be embodied in the document describing it, property having a documentary, as distinguished from an immediate physical, existence will be considered intangible in the discussion to follow.

\section{II}

\section{Conflict Avoidance}

\section{A. The Creation of Inter Vivos Trusts of Movables}

There are two essential requirements for conflict avoidance by counsel: the first, of course, is that counsel shall be knowledgeable and careful; the second is that there be a coherent body of rules from which he can derive guidance. With respect to the conflict rules governing the creation of inter vivos trusts of movables, there is a

" "For the time being . . . jurisdiction to tax parts company with general conflict of laws problcms." Eliott E. Cheatham, Noel T. Dowling, Herbert F. Goodrich, Erwin N. Griswold, Cases and Materials on Conflict of Laws I13 (I947 Supp.)

${ }^{5}$ See Walter W. Land, Trusts in the Conflict of Laws c. 8 (1940).

Restatement, Trusts \$2 (1935).

${ }^{7} I d . \$ 3$.

${ }^{8}$ See In re Berchtold, [1923] I Ch. 192; Walter W. CoOK, The Logical and Legal Bases of tuiz CONFLICT OF LAWS c. 12 (1942). 
wide gamut of authoritative statement, once we pass the threshold of formal validity.

To begin with, Professor Beale tersely stated that ". . . the law of the situs of a chattel determines its transfer inter vivos," and "there is no reason why this general rule should not be applied to the transfer of chattels into the hands of a trustee."1) Furthermore, ${ }^{11}$

A sale or gift of money or securities is governed by the law of the place where the money is deposited or the cash or securities are kept at the time of the sale or gift, and not at the domicil of the owner.

This is equally true, both on principle and on authority, of a gift of money or securities in trust.

A few years later, he observed that ${ }^{12}$

... the question of the validity of a trust of securities has come up, and it has been decided that its validity is governed by the law of the situs of the securities . . . the only authority to the contrary is an ill-considered dictum.... The law governing the validity of a trust of intangibles [i.e., other than "securities"] cannot be stated with confidence.

Reflecting Professor Beale's general assurance is the Restatement: ${ }^{13}$

The validity of a trust of choses in action created by a settlement or other transaction inter vivos is determined by the law of the place where the transaction takes place.

Comment f. When claim embodied in document. If a chose in action is evidenced by a document in which, by the law of the state where it was issued, the title to the obligation is embodied, a transaction purporting to create a trust therein is governed by the law of the state where the document is at the time of the transaction.

Unfortunately for the Restatement, however, Professor Cavers undermined its whole approach to inter vivos trusts of movables in an examination of its Tentative Draft in which he observed: $:^{14}$

But if we expect to find in the cases the clear-cut, if complex, process which the Restatement rule suggests, that expectation will be disappointed. Decisions frequently cited turn out only too often to be dicta, but even these may not be disregarded where square holdings are rarities.

As to what the courts actually are doing when faced with a challenge to the validity of a trust, a question as to whether, in fact. a trust has been created, Professor Cavers concluded:15

${ }^{\circ}$ Beale, Living Trusts of Movables in the Conflict of Laws, 45 Harv. L. Rev. 969, 970 (1932).

${ }^{10}$ Ibid. See also 2 Joseph H. Beare, a Treatise on the Conflict of Laws ior8 (1935). No doubt seems to exist as to the law governing the creation of an inter vivos trust of movable chattels, so this topic will not be further pursued.

${ }^{12}$ Beale, stpra note 9, at 970-7r.

${ }^{13}$ BEALE, Op. cit. supra note IO, at rorg-20.

${ }^{23}$ Restatement, Conflict of LAws \$294(2) (1934).

${ }^{16}$ Cavers, Trusts Inter Vivos and the Confict of Laws, 44 HaRv. L. Rev. 161, 174-75 (193I).

${ }^{25}$ Id. at xgr; cf. Hutchison v. Ross, 262 N. Y. $38 \mathrm{I}$, I87 N. E. 65 (1933); In re Jarvie's Trust, 73 N. Y. S. $2 d 246$ (Sup. Ct. r947). 
There is a weighing of various considerations-domicil, situs, place of execution, place of administration, form of instrument-a vague evaluation on the basis of which the court finds the law of one jurisdiction or another the proper law or the intended law. One cannot blind oneself to the weight placed on the intent of the settlor with reference to the selection of the governing law.

Judge Goodrich, in the latest edition of his text on the conflict of laws, states firmly in black letters: "The validity of . . . a trust crea[t]ed inter vivos [is determined] by the law of the situs of the property"; ${ }^{16}$ but after discussing several important cases, he concludes with less assurance: "If these cases may be considered typical, it would appear that no single rule of reference can be laid down for determining the validity of trusts inter vivos."17

Professor Stumberg is more cautious in his black-letter comment: ${ }^{18}$

It has been held that the valid creation of a trust inter vivos is a matter for the law at the situs, whether the subject matter is land or personalty.

In the discussion that follows, he adds that ". . . there is considerable confusion in the cases dealing with the creation of a trust inter vivos of movable property"10 and then goes on: ${ }^{20}$

The growing practice of creating trusts inter vivos makes it exceedingly important that some satisfactory rule be determined upon and applied generally so that settlors may be adequately advised in advance as to the legal effect of contemplated trust instruments. Advice of counsel is habitually sought in trust transactions, but with the present state of the authorities, such advice frequently cannot be given with certainty.

Another writer, after enumerating the interstate factors weighed by courts in passing on the validity of inter vivos trusts of movables, selected as ". . . two of the most important factors ... the domicil of the creator and place of execution of the trust. . . ."21

Nor are the treatises on trusts very helpful on the conflict of laws. Scott's index does not reveal any reference to the conflict of laws concerning the creation or validity of any type of trust. ${ }^{22}$ Bogert states that ". . . while in general the . . . legality of a trust of personalty [has been determined] by the law of the settlor's domicile, there are many opportunities for complication and variation," merates the elements that have influenced different courts in passing on the validity of trusts. In Perry, we learn that "the general rule, that the validity of an attempted trust is to be determined by the law ... of the domicile of the donor . . . if the prop-

${ }^{16}$ Herbert F. Goodrich, Handbook of the Conflict of Laws 490 (3d ed. 1949).

${ }^{17} I d$. at 492 .

${ }^{18}$ George W. Stumberc, Principles of Conflict of Laws 431 (2d ed. 195i).

${ }^{20} \mathrm{Id}$. at 433 .

${ }^{20}$ Ibid.

${ }^{31}$ Swabenland, The Confict of Laws in Administration of Express Trusts of Personal Property, 45 Yale L J.. 438, 449 (I935). See also Mayo A. Shatruck, An Estate PlanneR's Handbook 330-34 (1948); Note, Trusts of Personalty and Conflict of Laws, 89 U. PA. L. Rev. 360 (194r).

224 Austin W. Scotr, The LAw of Trusts 2839 (1939).

${ }^{38}$ ia George G. Bogert, The Law of Trusts and Trustees 327 (I95x). 
erty consists of personalty, is subject to considerable qualification . . .,"24 which is then discussed in less than two pages. And Nossaman summarizes his short section on the subject in these words: ${ }^{25}$

The law of the situs-that is, of the state of residence of the trustee-ordinarily governs the validity of inter vivos trusts. But the intent of the parties that the law of the domicile should govern will be applied to a rather indeterminate extent....

The most comprehensive examination of the authorities on the conflict of laws in the creation of inter vivos trusts of movables was undertaken by the late Walter W. Land in 1940, and he thus summarized the situation as it then appeared: ${ }^{26}$

In New York and New Jersey, although the domicil of the settlor was formerly accorded particular importance and in some cases furnished the governing law, recent decisions have transferred this emphasis from the settlor's domicil to the location of the trust property. Other elements of the trust are also considered, as the place where the trust instrument was executed, the domicil of the trustee, and the place in which the business of the trust is carried on. In the scattered opinions in states other than New York and New Jersey, apparently the domicil of the settlor is still considered of somewhat greater importance than any other single factor of the trust, although it will be outweighed by the remaining factors coinciding in another state. In all of the states which have passed on the question, an express intent of the settlor as to the governing law, combined with one or more important elements of the trust in the state selected, has caused the internal law of the designated state to govern.

The case law since I940 has not produced any startling changes, but rather exhibits a continuation of the trend that Land described. Recent decisions have given effect to stipulations in the indenture as to the governing law, ${ }^{27}$ and others have discerned an implied intent as to the governing law by weighing the distribution of the elements of the trust. ${ }^{28}$ Nevertheless, there are still courts that apply somewhat mechanically the law of the situs of the trust ${ }^{29}$ or the law of the domicile of the settlor. $^{30}$ What makes all such summaries misleading, however, is the persistence of the courts in mentioning alternative bases for the choice of law, which introduces confusion as to the test actually employed-a strict implied intent or the place of predominant contacts.

a I Jatrus W. Perry, A Treatise on the Law of Trusts and Trustees \$72a (7th ed., Baldes 1929).

26 I Walter A. Nossaman, Trust administration and Taxation 120 (i945).

${ }^{20}$ LAND, op. cit. supra note 5 , at rog. Because of the careful and comprehensive analysis of the inter vivos trust cases up to $194^{\circ}$ in Land, cases cited hereafter will be principally those decided since 1940.

${ }^{27}$ E.g., National Shawmut Bank v. Cumming, 325 Mass. 457, 91 N. E. 2d. 337 (1950); Haase v. Title Guarantec \& Trust Co., 295 N. Y. 76r, 66 N. E. $2 d$ 126 (1946); City Bank Farmers Trust Co. v. Meyn, 263 App. Div. 671, 34 N. Y. S. 2d 373 (2d Dep't r942).

${ }_{28}^{2 B}$ E.g., In re Davis' Trust, 133 N. Y. S. 2d 525 (Sup. Ct. I954); Application of Eyre, 133 N. Y. S. 2d 5 I I (Sup. Ct. 1954); In re Griswold's Trust, 99 N. Y. S. $2 d 420$ (Sup. Ct. 1950); In re O'Connor, 82 N. Y. S. 2 d 310 (Sup. Ct. 1948); First Central Trust Co. v. Claflin, 73 N. E. 2d 388 (C. P. Ohio 1947).

${ }^{20}$ E.g., Warner v. Florida Bank \& Trust Co., 160 F. 2 d 766 (5th Cir. I947); In re Piazza's Estate, I30 N. Y. S. 2d 244 (Surr. Ct. I954).

${ }^{30}$ E.g., David v. Atlantic Society, 129 N. J. Eq. 896, I9 A. 2d 896 (I94I). 
Of course, the simplest way to avoid a conflict of laws over the validity of an inter vivos trust of movables is to plan it so that it has no substantial connection with more than a single state. If the settlor is domiciled in state $X$, have him execute the indenture there, select a trustee to administer the trust there, assemble the corpus of the trust there, deliver it to the trustee there, etc. A conflict of laws affecting such a trust, then, will be likely to arise only in the event that the trust is moved elsewhere.

There is also considerable support in the cases for the proposition that counsel drafting the indenture for an inter vivos trust of movables can select the law by which the validity of the trust shall be determined, ${ }^{31}$ provided the law is that of a jurisdiction which has connection with at least some element of the trust. ${ }^{32}$ While this can be done with respect to many trust matters where the law of a given jurisdiction is deemed preferable to that which would otherwise apply, it should be noted that if public policy would thereby be subverted, the expression of intent may be ignored. ${ }^{33}$

The New York Personal Property Law seems specifically to recognize and give effect to the expressed intent of the settlor in these matters: ${ }^{34}$

Whenever a person being a citizen of the United States, or a citizen or a subject of a foreign country, wherever resident, creates a trust of personal property situated within this state at the time of the creation thereof, or of which the trustee is a resident of this state, or a domestic corporation or national bank located within this state, duly authorized by law to act as trustee, and declares in the instrument creating such trust that it shall be construed and regulated by the laws of this state, the validity and effect of such trust shall be determined by such laws.

Therefore, to paraphrase slightly a clause in use in one law office in New York City, a draftsman in New York might insert the following in the indenture: ${ }^{35}$

I hereby direct, in accordance with Section I2-a of the Personal Property Law of the State of New York, that the validity and effect of the dispositions in trust made by me herein shall be determined by the Laws of the State of New York.

Another suggested clause, for more general use, is: ${ }^{36}$

The validity, construction, effect and administration of this agreement shall be governed and determined under the laws of the State of [e.g., New York].

${ }^{31}$ E.g., Kitchen v. New York Trust Co., $292 \mathrm{Ky} .706,168 \mathrm{~S}$. W. 2d 5 (1943); Shannon v. Irving Trust Co., 275 N. Y. 95, 9 N. E. 2d 792 (1937); see also cases cited note 27, stupra.

${ }^{32}$ E.g., City Bank Farmers Trust Co. v. Cheek, 93 N. Y. L. J. 2941, June 7, 1935 (N. Y. Sup. Ct.).

${ }^{33}$ E.g., Matter of Adriance, ${ }_{5} 8$ Misc. 857, 286 N. X. Supp. 936 (Surr. Ct. 1936) (testamentary trust; public policy against perpetuities; additional facts stated in LAND, op. cit. stipra notc 5, at II9). But see, e.g., Shannon v. Irving Trust Co., 275 N. Y. 95, 9 N. E. 2d 792 (1937); City Bank Farmers Trust Co. v. Cheek, I Io N Y. S. $2 \mathrm{~d} 434$ (Sup. Ct. 1952); and Note, Use of a Foreign Trust to Avoid the New York Rule Against Perpetuities, 29 ST. John's L. Rev. 247 (1955).

${ }^{34}$ N. Y. Pers. Prop. Law $\$ 12-\mathrm{a}$. Cf. In re Ash's Trust, III N. Y. S. $2 d 115$ (Sup. Ct. 1952). See also R. I. Gen. Laws c. 486 (1938), as amended by R. I. Acts \& Resolves 1941, c. 977, adding new $\$ \$ 23,24$.

${ }^{36}$ Swabenland, supra note $2 \pi$, at $45 \mathrm{I}$.

${ }^{30}$ LAND, op. cit. supra note 5 , at 124 . 
Even where the indenture contains no express direction as to which law is to govern the trust, however, a number of courts have effectuated the implied intent of the settlor as inferred from the indenture and the circumstances surrounding the trust. As one court put it, "Here there is no express declaration of intention, but the intention is implied in every act and word of the parties." ${ }^{\text {"37 }}$ In any event, where it is inexpedient specifically to express an intent as to the law governing a trust, counsel may still strongly influence a court in its determination of the proper law by grouping as many of the elements of the trust as possible in the desired state.

Where these conflict avoidance techniques have not been employed in drafting the indenture, however, a thorough investigation of the cases up to I940 led Land to conclude that ${ }^{38}$

... after a trust has been created $\ldots$ it is no longer possible to plan the law to govern.

The only contrary cases he found were a group of New York decisions in which appointment of a New York trust to an extrastate charity was upheld under the law of the second state even though it would have been invalid under New York law. ${ }^{30}$

Since 1940, however, there have been indications that even after its creation, counsel may so shift the location of the important elements of a trust that its validity will be determined by the law of another state. The leading case in point is Wilmington Trust Co. v. Wilmington Trust Co., ${ }^{40}$ which involved an inter vivos trust of movables established in New York by a New York domiciliary. The indenture provided that a majority of the adult beneficiaries, with the approval of the settlor, if still living, could change the trustee. After a number of years, in place of the New York trustee, a Delaware bank was appointed trustee, and the corpus of the trust was transferred to Delaware. The instant litigation turned on whether New York or Delaware law governed the validity of the exercise of a power of appointment under the indenture, ${ }^{41}$ and the court held that the trust had properly been transformed from a New York into a Delaware trust and that Delaware law thenceforth governed its validity and powers granted under it.

An even more peregrinating trust was considered in a North Carolina case in the same year. ${ }^{42}$ Plaintiff, as settlor and life beneficiary, established an inter vivos trust of movables, possibly in England. Later, she amended the indenture and transferred the corpus to an Illinois bank as trustee, waiving, at the same time, the right to revoke which the indenture contained. Subsequently, she became a resident of

${ }^{37}$ Hutchison v. Ross, 262 N. Y. 381, 395, I87 N. E. 65, 7I (I933), I9 CoRNelx L. Q. 282 (I934); accord, National Shawmut Bank v. Cumming, 325 Mass. 457, 9I N. E. 2d 337 ( 1950 ). See also cases cited note 28 stipra.

${ }^{38}$ LAND, op. cit. stupra note 5 , at 130 .

${ }^{30}$ E.g., Robb v. Washington \& Jefferson College, 185 N. Y. 485,78 N. E. 359 (Ig06); Manice v. Manice, 43 N. Y. 303 (187I) (testamentary trust). See also Curtis v. Curtis, I85 App. Div. 391, 173 N. Y. Supp. Io3 (Ist Dep't 19 18 ).

${ }^{\circ} 24$ A. 2d 309 (Del. 1942), 30 Geo. L. J. 788 (1942).

"1 On conflict of laws problems peculiar to powers of appointment, see Casner, Estate PlanningPowers of Appointment, 64 HARv. L. REv. 185, 208-ro (x950):

${ }^{42}$ MacMillan v. Branch Banking \& Trust Co., 22I N. C. 352,205 S. E. $2 d 276$ (1942). 
North Carolina and appointed as trustee a North Carolina bank, which balked when she thereafter sought to terminate the trust with the consent of the remainderman. To the Supreme Court of North Carolina, the case seemed to present no serious difficulties: it noted that the settlor and life beneficiary had become a North Carolina resident, that a North Carolina bank had become the trustee, and that the situs of the trust was in North Carolina, and, accordingly, it applied a North Carolina statute on termination of trusts, without any consideration of the effect of the prior waiver under Illinois law.

A Pennsylvania case in the following year, although couched in terms of jurisdiction rather than the validity of the trust involved, did grant the beneficiary's petition to accept the resignation of the original trustee in Delaware and to appoint a Pennsylvania trustee instead. ${ }^{43}$ The decision emphasized the many connections the trust had always had with Pennsylvania, however, so it is not as strong a holding as the above two cases. ${ }^{44}$

While it cannot be said that changes in the distribution of the elements of the trust among various states will necessarily vary the governing law, ${ }^{45}$ it would, nevertheless, seem prudent to insert in the indenture a clause authorizing a change in the situs of the trust for good reasons. And in effecting such a change in situs for an existing trust, it would also be desirable for counsel to cancel any designation of a local agent to accept service of process and to cancel likewise any undertakings to account to a local court. ${ }^{46}$

\section{B. The Construction of Inter Vivos Trusts of Movables}

"Construction" of inter vivos trusts of movables here refers not to the legal effect of words used in the indenture, but rather to the meaning of the words. ${ }^{47}$ In this connection, if the court has sufficient information, it will infer therefrom the intent of the parties; but if such information is not available, it will, of necessity, have to rely on presumptions as to what was intended. Because the cases fail to distinguish nicely between such "interpretation" and resort to presumptions, both processes are here embraced by the term "construction." 48

Professor Beale initially did not recognize any distinction between the construction of an indenture and the administration of a trust, flatly asserting that "any ques-

${ }^{43}$ Appeal of Schoble, 346 Pa. 318, 30 A. 2d 316 (1943).

"Other recent cases on change of situs include In re Griswold's Trust, 99 N. Y. S. $2 \mathrm{~d} 420$ (Sup. Ct. 1950); Application of New York Trust Co., 195 Misc. 598, 87 N. Y. S. $2 d 787$ (Sup. Ct. 1949) and Matter of Shipman, 179 Misc. 303, 40 N. Y. S. 2d 373 (Surr. Ct. 1942).

${ }^{25}$ The persistence of the traditional view that the validity of an inter vivos trust of movables will be governed always by the law applicable at its creation is illustrated by David v. Atlantic County Socicty, I29 N. J. Eq. 501, 19 A.2d 896 (1941).

"See Capron, Situs of Trusts in Confict of Lawus, 93 Trusts \& Estates 878 (1954).

"7 Restatement, Conflict of Laws $\$ 296$ (1934). See, e.g., Goodrich, J., in Robinson v. Chance, 213 F. 2d 834 (3d Cir. 1954).

${ }^{\$ 8}$ See Restatement, Conflict of Laws $\$ 214$, comments $b, c$ (1934). 
tion which arises after the trust has come into being is a question of the administration of the trust," ${ }^{30}$ and concluding that ${ }^{50}$

All matters of administration are determined by the law of the situs or seat of the trust. The situs of a trust must be determined by an interpretation of the words by which the trust is created. No rule of law can be laid down for the purpose of interpretation. All indications are considered, such as the intention of the parties, the place of business or domicil of the trustee, the location of the trust res, and other similar factors.

Later, however, he admitted this qualification $:^{51}$

The interpretation of an instrument creating a trust of personalty is, in the absence of strong inference to the contrary, to be made according to the usage of the domicil of the settlor.

The Restatement, it will be no surprise to discover, takes much the same view, with an added reference to the time element: ${ }^{52}$

The meaning of the words used in an instrument creating a trust of movables is, in the absence of controlling circumstances to the contrary, determined in accordance with usage at the domicil of the settlor of the trust at the time of the execution of the instrument which created it.

\section{Professor Cavers, however, reached quite different conclusions: $:^{53}$}

It is submitted, therefore, that (I) an express declaration of intention as to the law desired by the settlor to govern his trust may properly be respected where the state whose law is so designated has a substantial connection with the transaction. (2) Where there is no such express declaration, the court should examine the facts of the transaction and the circumstances surrounding it in an effort to ascertain and effectuate any intent which is inferable therefrom. (3) In a wholly colorless transaction the law of the place of administration of the trust should be applied.

To Judge 'Goodrich, like Professor Beale, all questions arising after the creation of a trust ". . . are those concerning the administration of the trust," 54 and "such matters are generally said to be governed by the law of the place where the trust is to be administered." 55 Professor Stumberg seems to take the same view. ${ }^{56}$

Walter W. Land, however, found in the cases support for the view that the construction of a trust agreement is distinguishable from the administration of the trust. He concluded that in construing the language of an inter vivos trust of 1947).

10 Beale, supra note 9, at 972. See also Erwin N. Griswold, Spendthrift Trusts 366 (2d ed.

${ }^{\circ}$ Beale, supra note 9 , at 972 .

21 BEALE, op. cit. supta note Io, at 1023 .

${ }^{62}$ Restatement, Conflict of Laws $\$ 296$ (I934). Cf. McGrath v. Ward, 91 F. Supp. 636 (D. Mass. 1950).

${ }^{63}$ Cavers, supra note 14, at I95. Cf. In re Cheney's Estate, I09 N. Y. S. 2d 704 (Sup. Ct. 1952) (settlor specified law to govern construction); Minot v. Minot, 319 Mass. 253, 66 N. E. 2 d 5 (1946) (only trustee and res in New York; New York law applied).

"Gooprich, op. cit. supra note 16 , at 492 .

${ }^{20}$ Id. at 493 . Accord, Noble v. Rogan, 49 F. Supp. 370 (S. D. Calif. r943).

${ }^{20}$ Stumberg, op. cit. supra note $\mathrm{I} 8$, at $43 \mathrm{I}$ et seq. To the same effect, see Swabenland, supra note 21 , at 440 et seq. 
movables, courts generally seem to apply the law of the state with which the trust has the most substantial connection. ${ }^{57}$

Relevant to possibilities for conflict avoidance in this area is the New York statute quoted above, which permits the settlor to direct that the "effect of such trust" well as its validity be determined by New York law, and which has been construed to mean that the trust's interpretation shall be governed by New York law. ${ }^{50}$ While authority for the proposition is sparse, it would seem reasonable to allow a settlor to specify the jurisdiction under whose laws the indenture should be interpretedjust as, as has been suggested, he may specify the jurisdiction under whose laws its validity should be determined. In fact, there do not seem to be public policy considerations militating against the former, as might be the case with the latter. ${ }^{00}$ Furthermore, since the settlor may stipulate in the indenture all the rules of interpre. tation he wishes, even to the point of reciting the laws of a given state, no contact between the elements of the trust and the jurisdiction whose law is chosen would appear to be necessary.

To avoid a conflict over construction, then, as to avoid a conflict over validity, ${ }^{01}$ a settlor should concentrate as many elements of a trust as possible in the specific state whose law he wishes to govern the interpretation of the indenture. An alternative arrangement, inconvenient because of the lengthy indenture that may be entailed, would be specification of the canons of construction desired, selected from the laws of any given state or states. This technique may be the only feasible one, however, where practical difficulties militate against a sufficient concentration of important elements of the trust within a chosen state.

But after an inter vivos trust of movables has been created, with considerable foresight perhaps having been exercised in order to avoid a conflict of laws over interpretation of the indenture, elements of the trust may be dispersed by circumstances from the single state in which the settlor had concentrated them. Of course, if the indenture either specifies the law of the state by which it is to be construed or has set out in detail the rules for its interpretation, such a dispersal may, have minimal effect. If, however, the settlor has relied solely on a concentration of elements of the trust in a particular state whose law he wished to govern its construction, the question then arises as to whether a conflict of laws may, nevertheless, be avoided and the settlor's wish effectuated.

${ }^{67}$ LAND, op. cit. stlpra note 5, at 190. Cf. Commissioner v. Brown, I22 F. 2d 800 (3d Cir. 194I) (predominant contacts with New York, whose law governed); Clark v. Continental National Bank, 88 F. Supp. 324 (D. Neb. 1949) (settlor, trustec, res in Nebraska; beneficiaries elscwhere; Nebraska law governed); In re Baekeland's Will, 124 N. Y. S. 2 d 126 (Sup. Ct. 1953) (settlor nonresident, rest of elements in New York, whose law governed); In re Gaffncy's Trust, 75 N. Y. S. 2d 675 (Sup. Ct. 1948) (stipulation that New York law was to govern); Guaranty Trust Co. v. Brunton, 74 N. Y. S. 2 d 254 (Sup. Ct. I947) (law of place of predominant contacts governed).

${ }^{08}$ N. Y. Pers. Prop. LAW $\$ 12-a$, note 34 supra.

${ }^{60}$ In re Ash's Trust, III N. Y. S. 2d II5 (Sup. Ct. 1952); In re Tabbagh's Estate, 167 Misc. 156, 3 N. Y. S. 2d 542 (Surr. Ct. 1938) (testamentary trust applying similar N. Y. Decedent's Est. LAW \$47).

${ }^{60}$ See cases cited note 33 supra.

${ }^{\text {B1 }}$ Cf. cases cited note 37 supra. 
Let us take, for example, the following case: A settlor, domiciled in New Jersey, has established an inter vivos trust of movables in New York, where he has executed the indenture, has turned over to a New York trust company and a New York domiciliary as co-trustees securities previously kept in a safe deposit box in New York, and has named as beneficiaries his two sons, both New York domiciliaries. At this point, the only connection the trust has with any state other than New York is the fact that the settlor is a New Jersey domiciliary, and it is believed that New York law would clearly be applicable to the construction of the indenture. ${ }^{62}$

Modifying the example somewhat, however, suppose that the two sons now move to California to live, and the individual co-trustee moves to Connecticut. Will these changes frustrate the intent of the settlor that New York law govern the trust's construction? Probably not, since the cases indicate that after the creation of an inter vivos trust of movables, the courts will still construe the indenture in accordance with the law of the state with which, at the time of creation, the trust had the most substantial connection. ${ }^{63}$ Yet, it is possible that Wilmington Trust Co. v. Wilmington Trust Co., although dealing with the question of validity rather than construction, may be some authority to the contrary, at least where the indenture envisaged some shift, in view of its broad language: $:^{64}$

There is no substantial reason why a donor, in dealing with that which is his own, may not provide for a change in the location of his trust with a consequent shifting of the controlling law. In an era of economic uncertainty, with vanishing returns from investments and with tax laws approaching confiscation, such a provision would seem to amount to no more than common foresight and prudence.

\section{The Administration of Inter Vivos Trusts of Movables}

Administration of a trust usually refers to such things as the activities of the trustee, the investment policy he follows, allocation of principal and income, the accounting by the trustee, and the right of termination by the beneficiary. ${ }^{65}$ That the administration of a trust may be subject to the law of a different jurisdiction than the one governing its construction is suggested by Wilmington Trust Co.v. Wilmington Trust Co., where the corpus had been moved from New York to Delaware: ${ }^{66}$

... the home of the trust was in this State, and, being subject then to local law, the validity and effect of his deed of appointment and of the rights and interests of the appointees thereunder are to be adjudged by the law of Delaware.

Other cases point in the same direction, ${ }^{67}$ although decisions continue to appear which

os Cf. In re Baekeland's Will, I24 N. Y. S. 2 d 126 (Sup. Ct. 1953).

${ }^{03}$ E.g., Brandeis v. Atkins, 204 Mass. 471, 90 N. E. 816 (19I0) (life beneficiary moved to another state); Cary v. Carman, Ir6 Misc. 463 , 190 N. Y. Supp. 193 (Sup. Ct. x921) (life beneficiary moved; successor trustee possibly in different state). But of. Curtis v. Curtis, I85 App. Div. 39I, I73 N. Y. Supp. 103 (Ist Dep't 19r8).

oi 24 A. $2 \mathrm{~d}$ at 314 .

${ }^{60}$ See Restatement, Conflict of Laws \$297, comment $a$ (I934).

${ }^{80} 24$ A. $2 \mathrm{~d}$ at $3 \mathrm{I} 4$.

${ }^{07}$ E.g., Estate of Cornelia V. N. Bedford, 96 N. Y. L. J. 1879 (Surr. Ct. 1936); Guaranty Trust Co. v. Leach, 168 Misc. 526,5 N. Y. S. $2 d 628$ (Sup. Ct. 1938); MacMillan v. Branch Banking \& Trust Co., 
hold that the laws of the same jurisdiction must necessarily govern both construction and administration. ${ }^{68}$

To say that the law of the situs governs the administration of a trust settles very little in the typical conflicts case, where the distribution of elements of the trust among a number of states makes ascertainment of the situs problematical. Here the Restatement suggests that ${ }^{60}$

... consideration is given to the provisions of the instrument, the residence of the trustees, the residence of the beneficiaries, the location of the property, the place where the business of the trust is to be carried on.

Professor Beale agrees that ${ }^{\text {i0 }}$

All matters of administration are determined by the law of the situs or seat of a trust. The situs of a trust must be determined by an interpretation of the words by which the trust is created ... all indications are considered, such as the intention of the parties, the place of business or domicil of the trustee, the location of the trust res, and similar matters.

To Professor Cavers, ${ }^{71}$ the choice of the law governing administration is simple where there is a corporate trustee-namely, the state where it operates, ${ }^{72}$ which is likely to be the same law as governs validity anyway. And another writer offers a comprehensive list of the elements on whose location courts have relied in determining the proper law governing administration: ${ }^{73}$

I. The domicil of the creator of the trust.

2. The place in which the trust deed was executed.

3. The language of the trust instrument.

4. The place of probate of the will.

5. The location of the trust property.

6. The domicil of the trustee.

7. The domicil of the beneficiary.

8. The place in which the business of the trust is carried on.

9. The intention of the creator.

[Footnotes omitted.]

To Judge Goodrich, while the intention of the settlor will be followed if stated, the place with which the trust has its "most substantial connection" ${ }^{\text {"4 }}$ will be the situs; but, he cautiously adds: "The decisions seem not inconsistent with this

221 N. C. 352, 20 S. E. $2 d 276$ (1942); Application of Griswold, 125 N. Y. S. 2 d 479 (Sup. Ct. 1953).

${ }^{\circ 8}$ E.g., MacMillan v. Branch Banking \& Trust Co., 221 N. C. 352 , 20 S. E. 2 d 276 (1942).

${ }^{\circ 0}$ Restatement, Conflicts of Laws \$297, comment $d$ (1934).

${ }^{70} 2$ BEALE, op. cit. supra note 10, at I024. Cf. In re Lowman's Trust, 92 N. Y. S. $2 d 238$ (Sup.

Ct. 1949) (Ohio settlor, trustee, and corpus in New York; New York law governs).

${ }^{71}$ Cavers, supra note 14 , at 190.

72 But see Gilbert T. Stephenson, Rights of Out-of-State Trust Institutions (Trust Div,, American Bankers Ass'n, 1944), and White, Need for Reciprocity on Rights of Out-of-Statc Trust Institutions, Trust Bull., Dec. I95I, p. 3 for implications that this may not always be so simple where a trust company administers a trust established in another state.

${ }^{73}$ Swabenland, supra note 21 , at $442-43$.

74 GoOdRICH, op. cit. supra note I6, at 493. 
view."75 Professor Stumberg feels, with the Restatement, that the law of the situs should govern administration but offers no help in determining the situs for this purpose and on the Restatement rule comments: ${ }^{76}$

There are cases which might be construed as so holding, but their language is frequently such as to indicate an intention to disregard the law of the place of administration as such.

Walter W. Land has also assembled a list of the elements of a trust whose connection with various states has been considered by courts in determining the law governing its administration, ${ }^{77}$ but, as a Canadian writer plaintively has observed: "No court appears to have listed in order of their importance the factors that should be considered."78

Thus, there does seem to be general agreement among these authorities that the intent of the settlor, expressed in the indenture, that the law of a given state govern administration will be followed; ${ }^{79}$ and that a predominance of the elements of a trust in one state will subject administration of the trust to the law of that state. More difficult, however, is the decision where the elements of a trust are more or less equally divided among several states; here, the courts must decide which elements of the trust are the most significant-and the domicile of the settlor, the domicile of the trustee, especially a corporate trustee, place of execution of the trust agreement, and location of the corpus are those that have emerged.

As a conflict avoidance mechanism again, the New York statute discussed above ${ }^{80}$ is sufficiently broad to enable a settlor to subject the trust to New York law where either the corpus or trustee is within the state. New York cases, both before ${ }^{81}$ and after $^{82}$ the statute, have permitted the settlor thus to prescribe the law to govern administration of the trust. And the more elaborate Rhode Island statute ${ }^{83}$ permits the administration of a trust under Rhode Island law ( $x$ ) where the trust is to be administered in Rhode Island and the corpus is in Rhode Island when the trust is created; (2) when it is to be administered in Rhode Island and at least one trustee is a resident of Rhode Island or a Rhode Island corporation; or (3) when the settlor is a Rhode Island resident. Accordingly, to avoid a conflict of laws governing administration where the trust is to be administered in or the settlor is a resident of Rhode Island, or where either the corpus or the trustee is in New York, the settlor

${ }^{75}$ Ibid.

${ }^{70}$ StUMberg, op. cit. stpra note I8, at 435.

${ }^{77} \mathrm{LAND}$, op. cit. supra note 5 , at $23 \mathrm{r}-34$.

${ }^{78}$ Hoar, Some Aspects of Trusts in the Conflict of Laws, 26 CaN. B. Rev. I415, I424 (1948).

${ }^{70}$ E.g., Greims v. Bankers Trust Co., 124 N. Y. S. 2d 594 (Sup. Ct. 1953); Application of Spitzmuller, 279 App. Div. 233, 109 N. Y. S. 2d x (Ist Dep't 195I).

${ }^{\text {so }}$ N. Y. Pers. Prop. LAW $\$ 12-2$, note 34 stipra.

${ }^{81}$ E.g., Matter of Morton, 129 Misc. 875, 224 N. Y. Supp. 77 (Surr. Ct. I 927).

${ }^{82}$ E.g., Shannon v. Irving Trust Co., 275 N. Y. 95, 9 N. E. $2 d 792$ (1937); Matter of Vanneck, 158 Misc. 704, 286 N. Y. Supp. 489 (Surr. Ct. 1936); Matter of Tabbagh, I67 Misc. 156,3 N. Y. S. $2 d 542$ (Surr. Ct. 1938) (testamentary trust).

${ }^{83}$ R. I. GEN. LAws c. 486 (r938), as amended by R. I. Acts and Resolves I94I, c. 977, adding new $\$ \$ 23,24$ (194I), note 34 supra. 
need merely comply with the respective statutes by expressly stating that either New York or Rhode Island law is to govern administration. And even in those states lacking a similar statute, it seems that an express intent stated in the trust agreement will prevail. 84

If, for any reason, it is inexpedient expressly to indicate this intent, however, the same result can be achieved by grouping as many elements of the trust as is possible in the state whose law is desired to govern. To rely unquestioningly on expectations that a court will find an implied intent that a given state's law governs administration, however, is to hope too much; here courts may unexpectedly reach different results.

After creation of the trust, however, a number of decisions state emphatically that such shifts of elements of an inter vivos trust of movables as change of domicile by the donor, ${ }^{85}$ by the beneficiary, ${ }^{86}$ and by the trustee, ${ }^{87}$ and moving the corpus to another state ${ }^{88}$ will not change the law governing administration of the trust. According to this view, the law governing its administration becomes fixed at the creation of the trust, and, regardless of any change, the applicable law will remain the same.

But not all states take this position. In Connecticut, for example, a statute specifically provides that when a nonresident becomes life beneficiary of a Connecticut trust with a child who is remainderman, the life beneficiary may have a new trustee appointed in the state of his residence, and the latter may bring a proceeding in Connecticut for the delivery of the corpus to him. ${ }^{89}$ While the statute makes no mention of what law shall govern administration and no cases consider this point, the state to which the corpus is removed would seem to be justified in applying its law to the administration of a trust where the settlor had not specified the law that was to govern. The Connecticut statute might be construed as an expression of unconcern over the trust by the state once the corpus had been duly delivered to the extrastate successor trustee.

In a number of other states, there are decisions indicating that shifts in the location of the elements of a trust will change the law that is to govern its administration,

${ }^{84}$ See, e.g., Codman v. Krell, I52 Mass. 2I4, 25 N. E. 90 (1890); Greenough v. Osgood, 235 Mass. 235, I26 N. E. 46I (1920); Liberty National Bank \& Trust Co. v. New England Investors Shares, 25 F. $2 \mathrm{~d} 493$ (D. Mass. 1928).

${ }^{85}$ E.g., Mercer v. Buchanan, 132 Fed. 50 r (C. C. W. D. Pa. 1904); Tudor v. Vail, 195 Mass, 18, 80 N. E. 590 (I907); Russell v. Joys, 227 Mass. 263, II6 N. E. 549 (I917).

${ }^{86}$ E.g., Mercer v. Buchanan, I32 Fed. 50r (C. C. W. D. Pa. I904); Codman v. Krell, 152 Mass. 214, 25 N. E. 90 (1890); Brandeis v. Atkins, 204 Mass. 47I, 90 N. E. 861 (1910); Farnum v. Pennsylvania Co., 87 N. J. Eq. 108, 99 Atl. I45 (Ch. 1916), aff'd, 87 N. J. Eq. 652, 10I Atl. 1053 (1917); Fell v. McCready, 236 App. Div. 390,259 N. Y. Supp. 512 (4th Dep't 1932), $a f d^{\text {th }}, 263$ N. Y. 602, I89 N. E. 7I8 (I933); Lewis v. County of Chester, 60 Pa. 325 (1869).

${ }^{87}$ E.g., Lewis v. County of Chester, 60 Pa. 325 (1869); Swetland v. Swetland, 105 N. J. Eq. 608,149 Atl. 50 (Ch. 1930), aff'd, 107 N. J. Eq. 504, I54 Atl. 907 (193I).

${ }^{88}$ E.g., Farmers and Mechanics' Savings Bank v. Brewer, 27 Conn. 600 (1858); First National Bank v. National Broadway Bank, I56 N. Y. 459 , 5x N. E. 398 (1898).

${ }^{80}$ Conn. Gen. STAT. $\$ 6895$ (r949). See also id. $\$ 6862$, Removal by foreign guardian of ward's personal property, and $\$ 6863$, Removal by foreign guardian of proceeds of sale of ward's real cstate. 
at least where the trust agreement itself is silent on the subject. Typically, in a recent case in which the situs of a trust was changed from New York to California, the court observed: ${ }^{90}$

The holding that the situs of this trust may be transferred to a sister state without offending our policy gives the trust mobility instead of rigidity. In these days, when inter vivos trusts are created with ever growing frequency, when State lines are crossed so easily and people maintain contacts in several States, a sympathetic approach to problems of this sort is more likely to lead to the effectuation of the true intent of the creator of the trust.

The difficulty faced by counsel, then, in drafting an indenture is that while he can ordinarily select the state in which administration will be initiated, he can scarcely predict whether unexpected shifts in the location of elements of the trust will result in bringing its administration within the purview of a court that will continue to apply the same law. Accordingly, it would seem-essential that this contingency be recognized and that an appropriate clause be inserted in the indenture. Such a clause might provide that the law of a given state should govern the trust's administration, wherever its elements might be located; or, on the other hand, provision might specifically be made for applying the law of a state to which such a shift might move the trust. The flexibility of the latter technique has some advantage in that it may enable a trust to escape a jurisdiction whose legislation, especially tax legislation, has become unduly burdensome.

Where a trustee changes the location of elements of the trust, typically his own domicile and the corpus of the trust, in order to violate the terms of the trust agreement, however, it seems clear that he cannot obtain any advantage that the different rules of administration of the second state might otherwise afford. Jurisdiction to call him to account exists in the courts of the second state ${ }^{91}$ where the law of the first state would measure the trustee's conduct, and it has even been held that a judgment against a dishonest trustee in the first state, obtained on substituted service, will be supported by the full faith and credit clause ${ }^{92}$ in the courts of the state to which an absconding trustee has fled. ${ }^{93}$

\section{III}

\section{Conclusion}

Because legislative rules for resolving the conflict of laws are rare, and, in any case, their fashioning must properly form a part of comprehensive conflict-of-laws legislation, counsel seeking to avoid a conflict of laws in inter vivos trusts of movables must examine and seek to utilize the principally judge-made rules now in use.

The law governing the creation of inter vivos trusts does not permit great pre-

${ }^{00}$ Matter of Matthiessen, 195 Misc. 598, 606, 87 N. Y. S. 2d 787 (Sup. Ct. 1949).

${ }^{01}$ See, e.g., Equitable Trust Co. v. Schwebel, 40 F. Supp. II2 (E. D. Pa. I94I) (delinquent trustee enjoined, however, to submit to jurisdiction of first state).

${ }^{03}$ U. S. Const. art. IV, \$r.

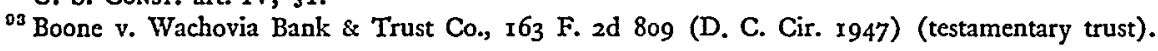


dictability, but any express statement in the trust agreement as to the law intended to govern is likely to be respected by the courts, provided some element of the trust impinges on the state whose law is specified. If, however, the law of the designated state contravenes the public policy of the forum, it may not prevail. If the settlor's intent is undiscernible, various states may test validity of the trust by the law of his domicile, by the law of the situs of the corpus, or by the law of the state with which the trust has the most substantial contacts. Furthermore, if the location of elements of the trust shifts after its creation, some states will look to the law of the successor state to determine its validity. Faced with this uncertainty, the wisdom of specifying in the indenture the law intended to govern validity of a trust is clear.

When a trust has been properly established, the law governing its construction, again, will usually be that specified in the indenture; and if none is specified, the courts tend to apply the law of the state with which the trust is predominantly related. Here, again, counsel can avoid conflicts by specifying the law that is to govern construction; and the possibility of a shift in the location of elements of the trust to another state can be dealt with by a statement as to the law to govern in that event.

While courts have not always been meticulous in distinguishing between what are problems of construction and what are problems of administration, counsel can state in the indenture that what are found to be questions of its administration shall be governed by a specified law, not necessarily the law governing its validity or construction. If this step is neglected, courts will follow the procedure of applying the law of the state having predominant contacts with the trust, often an unpredictable matter where there are elements of the trust scattered among several states. There seems to be more leeway in the area of administration of trusts (as compared with validity or construction), which permits application of a different law if the trust moves to another state; courts seem to be willing to apply the law of the forum after a shift occurs. Covering the possibility of such a shift by a provision in the trust agreement should help effectuate the settlor's intent with respect to the law intended to govern administration of the trust.

One of the most perplexing conflict problems facing lawyers drafting trust agreements has, of necessity, been ignored. Although suggestions have been offered to relate a given trust to a selected state for various purposes and even to provide for shifts to other states, no help can be given in foreseeing what state laws in the future will be advantageous or disadvantageous. For that problem the most cunning draftsman has only his crystal ball. 